\title{
Taxonomy and palaeoceanographical significance of the genus Krithe (Ostracoda) in the Brazilian margin
}

\author{
DERMEVAL APARECIDO DO CARMO ${ }^{1,2} \&$ YVONNE T. SANGUINETTI ${ }^{2}$ \\ ${ }^{1}$ Universidade de Brasília. Instituto de Geociências. BRAŚLIA, DF, BRAZIL, CEP 70.910.900. \\ ${ }^{2}$ Universidade Federal do Rio Grande do Sul, Instituto de Geociências, Departamento de Paleontologia e Estratigrafia, Caixa Postal 15001, Porto \\ Alegre, RS, Brazil, CEP 91501-970.
}

\begin{abstract}
The results of taxonomic, geographical distribution and palaeoecological studies of the genus Krithe from the Brazilian continental margin are presented. The following species and subspecies are recognized: Krithe reversa Bold, 1958; $K$. trinidadensis Bold, 1958; K. morkhoveni morkhoveni Bold, 1960; $K$. coimbrai sp. nov.; and $K$. gnoma sp. nov. Four species are left in open nomenclature. The occurrence of Krithe within the Brazilian continental margin is restricted to areas under the influence of cold waters and, considering their stratigraphic distribution in Cenozoic strata, they are here recognized as being useful as palaeoceanographic indicators. Of the above-mentioned species, only two occur within the Brazilian continental shelf; these are $K$. coimbrai and $K$. gnoma. These species are eurybathic and their occurrences in a shelf environment are restricted to areas under the influence of the Falkland Current. Considering their stratigraphic distribution within the Pelotas Basin, southern Brazil, and their association with other coldwater taxa, including species of foraminifera, it is here suggested that the Falkland Current was already operating in the Miocene. J. Micropalaeontol. 18(2): 111-123, December 1999.
\end{abstract}

\section{INTRODUCTION}

This paper presents a taxonomic and palaeocological study of Krithe reversa Bold, 1958, K. Trinidadensis Bold, 1958, K. $m$. morkhoveni Bold, 1960, K. coimbrai sp. nov., K. gnoma sp. nov. and four species left in open nomenclature. Considering that their Recent geographical distribution is related to different oceanographic conditions within the Brazilian continental margin, it is possible to characterize their ecological setting. Their stratigraphic distribution and palaeoceanographical significance is also discussed.

A palaeoceanographical approach is undertaken as the occurrences of $K$. coimbrai and $K$. gnoma in the Miocene of the Pelotas Basin, as verified by the present workers, is used here as a parameter for palaeoceanographical analysis of the Falkland current. Also, a discussion concerning the establishment of the proto-NADW (North Atlantic Deep Water) is presented with reference to the geographical and stratigraphic distribution of the psychrospheric species $K$. reversa, $K$. trinidadensis and $K$. m. morkhoveni.

\section{STUDY AREA}

The Brazilian continental margin is located on the eastern border of the South American plate. It is subdivided into three physiographic provinces: shelf, slope and continental rise. Areas of the Brazilian continental margin, in terms of geographical classification, are here referred to as northern, eastern and southern (Fig. 1). The continental shelf slopes at an average of $0.1^{\circ}$. The northern and eastern continental shelves extend from the coastline to isobaths of $40 \mathrm{~m}$ and $70 \mathrm{~m}$. The southern continental shelf reaches from $100 \mathrm{~m}$ to $160 \mathrm{~m}$. The continental slope is inclined at an average of $4^{\circ}$ to $5^{\circ}$. The boundary between the slope and the continental rise occurs within the bathymetric interval of $2,800 \mathrm{~m}$ to $3,600 \mathrm{~m}$. The continental rise extends to depths 4800-5400 m (Chaves, 1983).

Four types of water masses influence the Brazilian continental margin: the Upper Water Mass, the Antarctic Intermediate
Water, the NADW and the Antarctic Bottom Water. The last three comprise the psychrosphere layer, which affects the marine biota on the slope and continental rise (Kennett, 1982; Bearman, 1989).

The upper water masses are represented by the Atlantic Central Water and Sub-Antarctic Water, which are strongly affected by surface currents. The currents South Equatorial, Brazil and Guianas, mainly on the northern and eastern margins, control the movement of the Atlantic Central Water. As a consequence of these currents, the northern and eastern shelves are under the influence of warmer water than the southern shelf (Martins, 1984).

The Falkland Current, which carries Sub-Antarctic waters to the southern Brazilian continental shelf, is responsible for the introduction of colder water to this shelf area (Boltovskoy, 1981). The influence of this current on the Brazilian continental shelf is felt as far north as $22^{\circ} \mathrm{S}$, in the Rio de Janeiro state (Boltovskoy, 1959; Vicalvi \& Milliman, 1977; Carmo \& Sanguinetti, 1995).

The Pelotas Basin is located on the southern Brazilian continental margin in an area that is also influenced by the Falkland Current. Most of the Pelotas Basin is located on the eastern part of the Rio Grande do Sul state, but it also extends north into part of the Santa Catarina state (Brazil) and south to Uruguay.

In Brazil, the onshore part of the basin extends from around $34^{\circ}$ to $28^{\circ}$ S (Sanguinetti, 1979; Gomide, 1989; Dias et al., 1994) and in shelf areas it reaches around $26^{\circ} \mathrm{S}$ (Koutsoukos, 1982; Dias et al., 1994). The southern location of the Pelotas Basin and the stratigraphic range of its sediments (Cretaceous to Quaternary) give this basin special importance in palaeoceanographical studies of the Falkland Current.

\section{MATERIAL}

Of the 1210 samples analysed, 1030 were from on bottom sediments collected by the REMAC and GEOMAR oceano- 


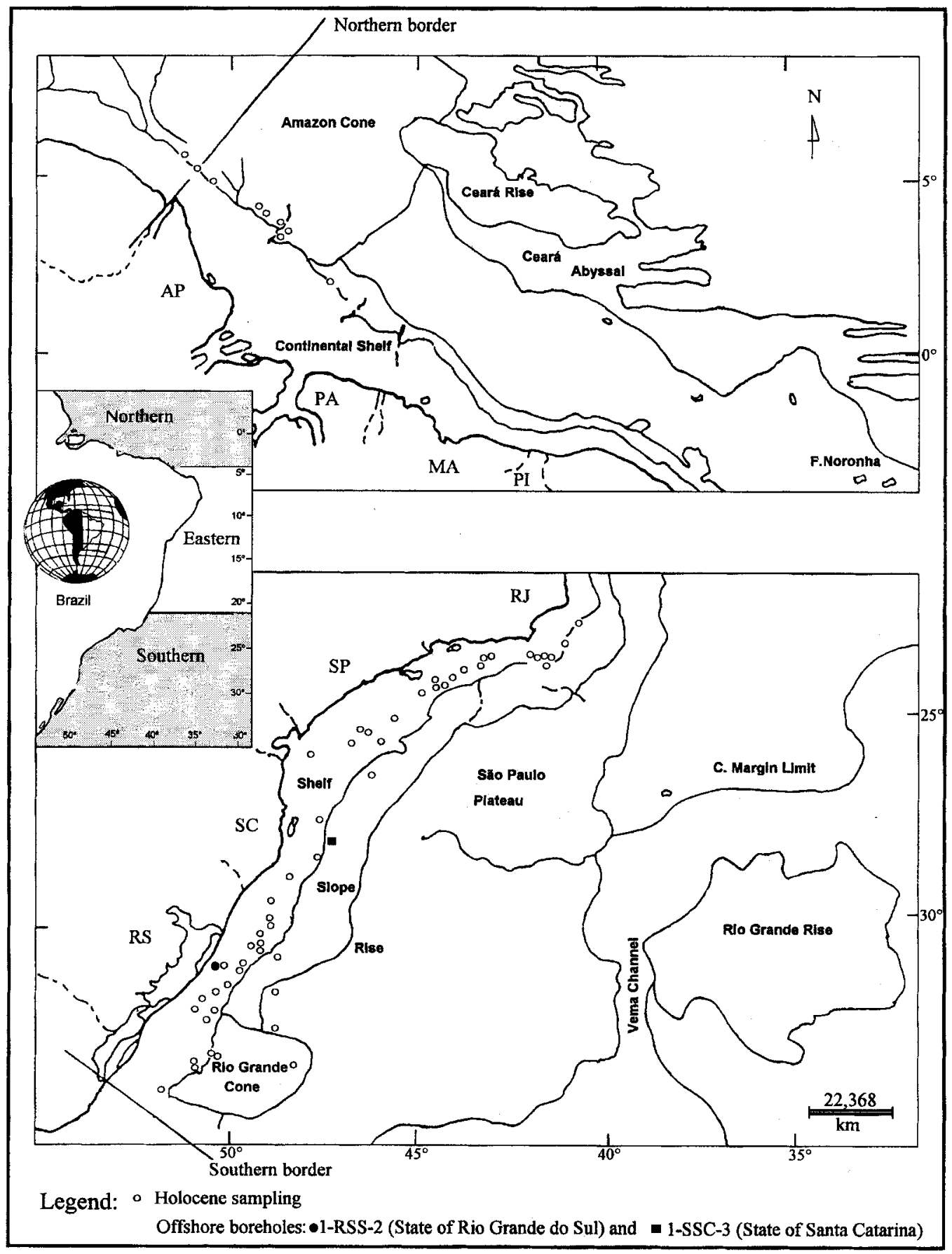

Fig. 1. Map of the Holocene sampling and of the boreholes 1-RSS-2 and 1-SSC-3. Adapted from Chaves (1983) and Coimbra \& Ornellas (1989).

graphic projects, and 180 were from offshore boreholes in the Pelotas Basin drilled by PETROBRÁS-Petróleo Brasileiro SA. Only 67 samples yielded specimens of Krithe.

Most of the 1030 samples were collected out in the northern and eastern margins. On the eastern margin this sampling was restricted to shelf areas, but deeper zones in the southern and northern margins were sampled (Fig. 1). From the total number of bottom sediment samples, Krithe occurred in only 62 . Analysis was also carried out on 179 cuttings samples of the borehole 1-RSS-2, where Krithe occurred in four samples, and one cuttings sample from the borehole 1-SSC-3 (Fig. 1).

\section{TAXONOMY}

The supra-generic classification herein follows that of Moore \& 
Genus Krithe (Ostracoda) in the Brazilian margin

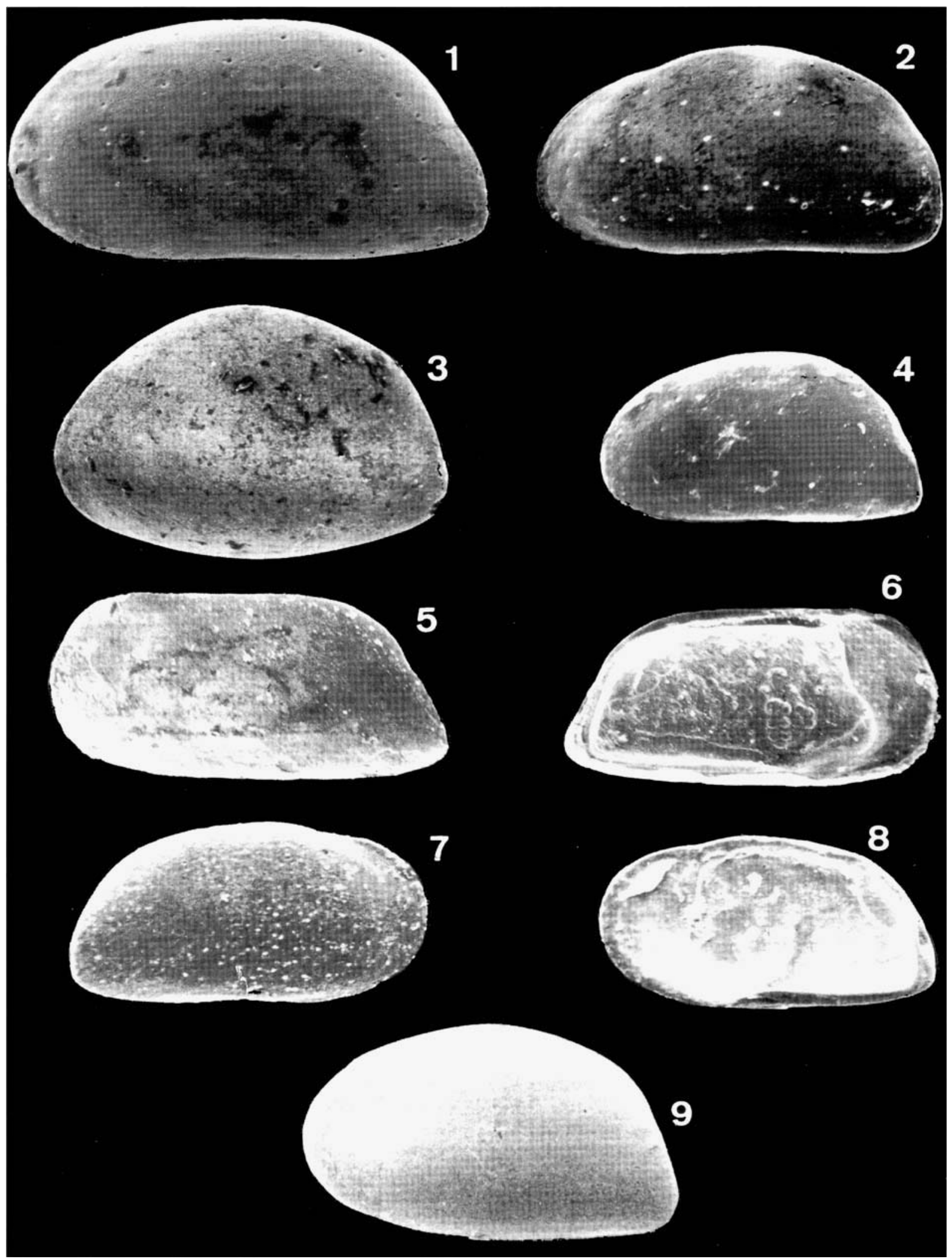

Explanation of Plate 1

fig. 1. ( $\times 93)$ Krithe morkhoveni morkhoveni Bold, 1960 (MP-O-1508), sample GVI/356, female left valve, external view. fig. 2. $(\times 80)$ K. reversa Bold, 1958 (MP-O-1509), sample G.VII/\#14, female left valve, 6th instar, external view. fig. 3. $(\times 79.5)$ K. trinidadensis Bold, 1958 (MP-O-1510), sample GVI/356, female, left valve, 6th instar, external view. fig. 4. (×79.6) K. sp. 2 (MP-0-1511), sample GVI/371, young instar, left valve, external view. figs 5, 6. $K$. sp. 3 (MP-O-1512), sample GII/116-141, adult, left valve; 5 ( $\times 84.9)$ : external view and $6(\times 75.3)$ : internal view. figs 7, 8. $K$. sp. 1 (unfortunatly damaged), sample GVI/358, adult right valve; $7(\times 73.6)$ : external view and $8(\times 65.8)$ : interval view. fig. 9. $(\times 69.4) K$. sp. 4 (MP-O1513), sample GVI/371, female, left valbe, external view. 
Pitrat (1961) and Hartmann \& Puri (1974). The nomenclature used to describe normal pore canals was proposed by Puri \& Dickau (1969) and that for marginal pore canals was established by Morkhoven (1962). With respect to oceanographic projects, the following conventions are employed: R, REMAC; L, leg; and $\mathbf{G}$, GEOMAR. Considering the specific frequency of carapace and/or valves, the following adjectives are used: rare (1-5 carapaces or valves), frequent $(6-10)$ and abundant (more than 11). The type material referred to in this paper is held in the 'Museu de Paleontologia da Universidade Federal do Rio Grande do Sul' prefixed by MP-O-.

Order Podocopida Müller, 1894

Suborder Podocopina Sars, 1866

Superfamily Cytheracea Baird, 1850

Family Krithidae Mandelstam, 1960

Genus Krithe Brady, Crosskey \& Robertson, 1874

Krithe reversa Bold, 1958

(Plate 1, fig. 2)

1958 Krithe reversa Bold: 399, pl. 1, fig. 4a--g.

1959 Krithe sawanensis Hanai: 301, pl. 18, figs 3-7, text-figs 3-4.

1967 Krithe producta Brady; Swain: 55-56; pl. 9, fig. 1.

1971a Krithe aff. K. bartonensis (Jones); Swain: 489, pl. 36.1, fig.7.

1976 Krithe producta Brady; Kaesler \& Lohmann: 280, fig. $1 \mathrm{~A}-\mathrm{B}$.

1981 Krithe reversa Bold; Bold: 69, pl. 13, figs a-b.

1981 Krithe reversa Bold; Steineck: 362, pl. 2, fig. 12.

1983 Krithe sp. C30 Peypouquet; Benson \& Peypouquet: 818, pl. 5, figs 4-5.

1987 Krithe reversa Bold; Steineck, Dehler, Hoose \& McCalla: 609 , fig. 5C.

1990 Krithe sp.4 Dingle, Lord \& Boomer: 282, figs 17D, 18F, 22E.

1992 Krithe sawanensis Hanai; Zhou \& Ikeya: 1101, fig. 3; 1109, figs 9.1-3; 1111, figs 10.1-2.

1993 Krithe sawanensis Hanai; Whatley \& Quanhong: 289, figs 3.1 and 3.2 .

1994 Krithe reversa Bold; Coles, Whatley \& Moguilevsky: 77, pl. 1, figs 1-6, text-figs 3A-D.

1995 Krithe sp. 4 Carmo \& Sanguinetti: 409, fig. 2E.

Figured specimen-MP-O-1509. Left valve, female, length $0.75 \mathrm{~mm}$, height $0.40 \mathrm{~mm}$.

Locality. Southern Brazilian continental slope, sample GVI/334, $33^{\circ} 2^{\prime} \mathrm{S} / 50^{\circ} 16^{\prime} \mathrm{W}, 900-950 \mathrm{~m}$ depth, hemipelagic sediments.

Horizon. Recent.

Material.- Rare. One adult and young instars disarticulated. Well preserved.

Remarks. The strong antero-dorsal concavity of the left valve of the female and its pocket-shaped anterior vestibulum makes this species easily identifiable. Krithe producta Brady, 1880 (in Swain, 1967), despite being a young instar, can be identified as $K$. reversa by the distinctive antero-dorsal concavity of the left valve and the reversed hinge, so that the hinge bar is clearly in the left valve. The material from the Strait of Magellan (sampled at $175 \mathrm{~m}$ depth) identified as $K$. producta, large forms (in: Kaesler \& Lohmann, 1976), actually is $K$. reversa.

Occurrence. Recent, southern Brazilian continental slope.

Geographical and stratigraphic distribution. North Atlantic and Caribbean, Middle Miocene to Recent (Coles et al., 1994; Bold, 1958, 1981; Steineck, 1981). South Atlantic, Upper Miocene (Benson \& Peypouquet, 1983) to Recent (Carmo \& Sanguinetti, 1995). Pacific Ocean, Middle Miocene (Steineck et al., 1987) to Recent (Swain, 1967, 1971a). Strait of Magellan, Recent, at $175 \mathrm{~m}$ depth, occurrence based on material loaned by Dr. R. Kaesler. Chinese Sea, Recent (Zhou \& Ikeya, 1992; Whatley \& Quanhong, 1993). Tertiary of the Central America (Bold, 1958, 1981) and in the Pliocene of the Japan (Hanai, 1959).

Krithe trinidadensis Bold, 1958 (Plate 1, fig. 3).

1958 Krithe trinidadensis Bold: 398, pl. 1, fig. 3a, 3c-f.

1969 Krithe producta Brady; Yassini: 82-83, fig. 4.

1971a Krithe aff. bartonensis (Jones); Swain: 491, pl. 36.3, fig. la-c.

1971b Krithe aff. bartonensis (Jones); Swain: 599, pl. 36.3, fig. 3.

1971 b Krithe bartonensis (Jones); Swain: 599, pl. 36.3, fig. 6.

1971b Krithe tumida Brady; Swain:599, pl. 43.1, fig. 4a-c.

1981 Krithe sp. 5 Ciampo: 67, pl. 6, fig. 7.

1981 Krithe sp. 6 Ciampo: 67, pl. 6, fig. 3.

1981 Krithe sp. 8 Ciampo: 67, pl. 6, fig. 4.

1983 Krithe sp. D21 Peypouquet; Benson \& Peypouquet: 808, pl. 5, fig. 8 .

1984 Krithe morkhoveni Bold; Steineck, Breen, Nevins \& O'Hara: 1473, figs E, I.

1990 Krithe rex Dingle, Lord \& Boomer: 276-79, figs $17 \mathrm{G}-\mathrm{H}$, $18 \mathrm{H}, 21 \mathrm{~A}-\mathrm{D}$.

1990 Krithe peypouqueti Dingle, Lord \& Boomer: 279-81, figs $17 \mathrm{~L}-\mathrm{M}, 18 \mathrm{~L}, 21 \mathrm{E}-\mathrm{F}, 22 \mathrm{~A}$.

1994 Krithe trinidadensis Bold; Coles, Whatley \& Moguilevsky: 99 , pl. 4, figs 7-9, figs 10-12; text-figs 4 P-T and $5 \mathrm{~A}-\mathrm{B}$.

1995 Krithe sp. 5 Carmo \& Sanguinetti: 409, fig. 2D.

Figured specimen-MP-O-1510. Female, left valve, length $0.73 \mathrm{~mm}$, height $0.49 \mathrm{~mm}$.

Locality. Southern Brazilian continental slope, sample GVI/356, $32^{\circ} 24.5^{\prime} \mathrm{S} / 48^{\circ} 42^{\prime} \mathrm{W}, 2860 \mathrm{~m}$ depth, hemipelagic sediments,

Horizon. Recent.

Material. Frequent. Disarticulated valves of several young instars. Adults at initial stage of dissolution were identified.

Remarks. The tumid shape of the female is typical of $K$. trinidadensis Bold, 1958.

Occurrence. Recent, northern and southern Brazilian continental slope.

Geographical and stratigraphic distribution. North Atlantic, Middle Eocene to Recent (Coles et al., 1994; Yassini, 1969). South Atlantic, Oligocene (Benson \& Peypouquet, 1983) to Recent (Dingle et al., 1990; Carmo \& Sanguinetti, 1995). Indian Ocean, Pliocene (Swain, 1971b). South Pacific, Pliocene to Holocene (Swain, 1971a, b). Tertiary of Central America (Bold, 1958; Steineck et al., 1984) and Europe (Ciampo, 1981). 
Genus Krithe (Ostracoda) in the Brazilian margin

Krithe morkhoveni morkhoveni Bold, 1960 (Plate 1, fig. 1)

1958 Krithe aff. producta Brady; Bold: 398, pl. 2, figs 3a, c-d, fig. $3 b$.

1960 Krithe morkhoveni Bold: 160, pl. 3, fig. 6.

1960 Krithe elongata Bold: 159, pl. 3, fig. 5a-c.

1960 Krithe cubensis Bold: 159, pl. 3, fig. 4a-b.

1961 Krithe langhiana Oertli: 24, pl. 3, figs 24-30.

1961 Krithe citae Oertli: 25, pl. 3, figs 31-32.

1961 Krithe contracta Oertli: 26, pl. 3, figs 35-38.

1964 Krithe luyensis Deltel: 171-72, pl. 4, figs 83-85.

1964 Krithe cf. contracta Oertli; Dieci \& Russo: 79, pl. 15, fig. 8.

1966 Krithe prolixa Bold:180 [new name for $K$. elongata, Bold non Jones].

?1968 Krithe aff. morkhoveni Bold; Russo: 39; pl. 6, fig. 4a,d, pl. 8 fig. 6 ; pl. 9 fig. $1 \mathrm{a}, \mathrm{c}$.

1968 Krithe trinidadensis, Bold; Bold: pl. 2, fig. 10a-b, fig. $10 \mathrm{c}-\mathrm{d}$.

1972 Krithe langhiana Oertli; Sissingh: 84, pl. 4, fig. 6a-b.

1974 Krithe aff. K. bartonensis (Jones); Leroy \& Levinson: 24, pl. 11, fig. ?4, pl. 12, fig.5.

1977 Krithe sp. D22 Peypouquet: 113, fig. 37.

1980 Krithe cancuensis ambigua Pokorný: 341, text figs 8-12, pl. 2, figs 2-3.

1980 Krithe kollmani Pokorný: 338, text figs 1-2; pl. 1, figs 1-3, pl. 2, fig. 1.

1981 Krithe prolixa Bold; Steineck: 359, pl. 1, fig. 13.

1983 Krithe sp. C Cronin: 116, pl. 10, figs A-C.

1983 Krithe sp. D22 Peypouquet; Benson \& Peypouquet: 808.

1983 Krithe sp. D'23 Peypouquet; Benson \& Peypouquet: 818, fig. 9.

1985 Krithe luyensis Deltel; Ducasse, Guernet \& Tambareau: 285, pl. 78, figs 11-13.

1987 Krithe reversa Bold; Steineck, Dehler, Hoose \& McCalla: 609 , fig. 5B.

1994 Krithe morkhoveni morkhoveni Bold; Coles, Whatley \& Moguilevsky: 94-96, pl. 3, figs 11-18, text-figs 4D-H.

1995 Krithe sp. 3 Carmo \& Sanguinetti: 409, fig. 2C.

Figured specimen-MP-O-1508. Female, left valve, length $0.75 \mathrm{~mm}$ and height $0.42 \mathrm{~mm}$.

Locality. Southern Brazilian continental rise, sample GVI/356, $32^{\circ} 24.5^{\prime} \mathrm{S} / 48^{\circ} 42^{\prime} \mathrm{W}, 2860 \mathrm{~m}$ depth, hemipelagic sediments.

Horizon. Recent.

Material. Frequent. Carapace and disarticulated valves, female, male and young instars. Well preserved.

Remarks. The subovate outline of the carapace and the greatest height just behind the middle (females) of these specimens are characteristic of Krithe m. morkhoveni.

Occurrence. Recent, southern Brazilian continental slope, depth ranges from $2500 \mathrm{~m}$ to $2860 \mathrm{~m}$.

Geographic and stratigraphic distribution. North Atlantic, Upper Palaeocene to Recent (Coles et al., 1994). South Atlantic, Upper Oligocene/Miocene (Benson \& Peypouquet, 1983) to Recent (Carmo \& Sanguinetti, 1995). Pacific, in the Middle Miocene to Quaternary (Steineck et al., 1987; Ayress, 1985, in Coles et al., 1994). Tertiary of Europe (Oertli, 1961; Deltel, 1964; Dieci \&

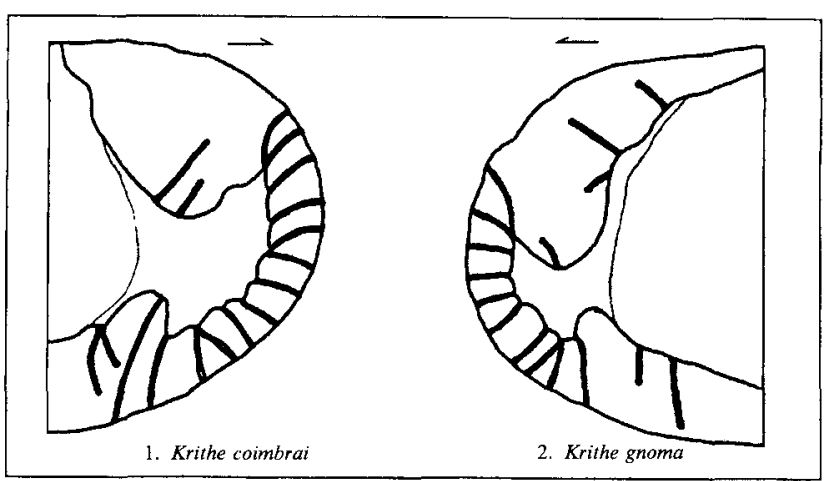

Fig. 2. Outline of the interior vestibulum. (1) Krithe Coimbrai sp. nov. and (2) K. gnoma sp. nov.

Russo, 1964; Sissingh, 1972; Pokorný, 1980; Ducasse et al., 1985), Central America (Bold, 1958, 1960; Steineck, 1981) and South America (Bold, 1966, 1968).

Krithe coimbrai sp. nov.

(Plate 2, figs 1-6; Fig. 2.1)

?1971a Krithe cf. Krithe glacialis Brady, Crosskey \& Robertson; Swain: 492, pl. 36.4, fig. 10.

1979 Krithe trinidadensis Bold; Sanguinetti: 169, pl. 4, fig. 2ab; pl. 10 fig. 4a-b.

?1983 Krithe sp. D12 Peypouquet; Benson \& Peypouquet: 818, fig. 7 .

1992 Krithe sp. Sanguinetti, Ornellas, Coimbra \& Ramos: 164, pl. 4, figs 8-14.

1995 Krithe sp. 1 Carmo \& Sanguinetti: 409, fig. 2.A.

1998 Krithe sp. 2 Whatley et al. pl. 2, figs 5-6.

Derivation of name. In honour of Dr. João Carlos Coimbra of the 'Universidade Federal do Rio Grande do Sul-UFRGS' in recognition of his contribution to the knowledge of Brazilian ostracods.

Holotype- MP-O-1503. Female, right valve, length $0.67 \mathrm{~mm}$, height $0.35 \mathrm{~mm}$.

Type locality. Southern Brazilian continental shelf, sample RL1/ $3064 ; 33^{\circ} 22^{\prime} \mathrm{S} / 50^{\circ} 54^{\prime} \mathrm{W}, 142 \mathrm{~m}$ depth; mud.

Horizon. Recent.

Paratypes. Males, sample RL1/3064. Paratype MP-O-1504, right valve, length $0.75 \mathrm{~mm}$, height $0.35 \mathrm{~mm}$. Paratype MP-O1505 , left valve, length $0.76 \mathrm{~mm}$, height $0.38 \mathrm{~mm}$.

Material. Abundant. Carapaces and disarticulated valves of females, males and young instars. Very well preserved.

Diagnosis. Krithe with slightly arched dorsal margin, greatest height in median area, mushroom-shaped anterior vestibulum with two characteristic false marginal pore canals in its anterodorsal area.

Description. Subovate in lateral view, greatest height in median area. Slightly arched dorsal margin, straight ventral margin. Anterior margin rounded, posterior truncated. External surface slightly punctate, perforated by normal pore canal of type ' $\mathbf{C}$ '. Asymmetrical valves; left valve larger than right. Dorsal margin more arched in the right valve and slightly concave towards the 
D. A. do Carmo \& Y. T. Sanguinetti

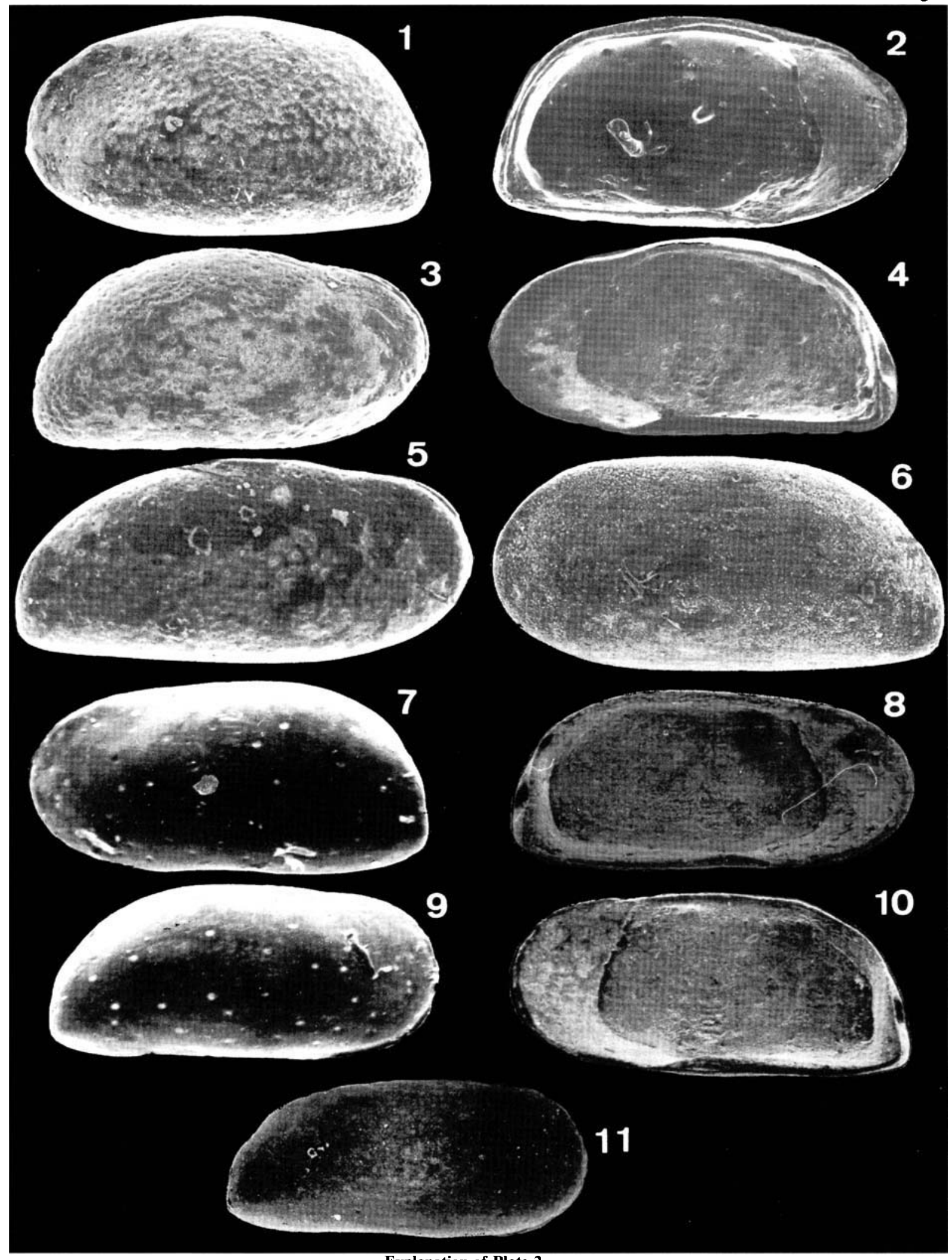

Explanation of Plate 2

Figs 1-6. ( $\times 91)$ Krithe coimbrai sp. nov. figs 1-4. Holotype MP-O-1503, sample RL1/3064, female carapace. figs 1, 2. Left valve (unfortunatly damaged); 1 external view, 2 internal view. figs 3, 4. Right valve; 3 external view, 4 internal view. figs 5, 6. Paratypes, sample RL1/3064, males, 5 paratype MP-O-1504, right valve and 6 paratype MP-O-1505, left valve. figs 7-11 (×94) K. gnoma sp. nov. figs 7-10. Holotype MP-O-1506, sample RL3/3122, female carapace. figs 7, 8. left valve; 7 external view, 8 internal view. figs 9, 10. Right valve; 9 external view, 10 internal view. fig. 11. Paratype MP-0-1507, sample RL3/3228, male, 7th instar, right valve, external view. 
anterior. Internally, four adductor muscle scars are disposed in a vertical row, the single frontal is trefoil, there are three dorsal muscle scars and a mandibular scar is present antero-ventrally. The marginal zone follows the outline of the free margin and through it pass marginal and false marginal pore canals. Anterior and posterior vestibula are present; mushroom-shaped with wide neck anteriorly and posteriorly, tube-shaped. Eleven marginal pore canals extend from the distal portion of the anterior vestibulum and, internally, there are two distinct false marginal pore canals in the antero-dorsal position and one antero-ventral bifid (Fig. 2.1). Strong sexual dimorphism; males more elongate and dorsal margin less arched than in females.

Remarks. This species differs from Krithe trinidadensis Bold, 1958 because of its less inflated outline, smaller size and anterior vestibulum lacking a long neck. It is similar to Krithe cf. $K$. glacialis Brady, Crosskey \& Robertson, 1874 (in Swain, 1971a, pl. 36.4, fig. 10), but it is here tentatively placed in synonymy because it is a young instar. Krithe sp. D12 Peypouquet (in Benson \& Peypouquet, 1983: 818, fig. 7) has an outline and type of anterior vestibulum that is very close to $K$. coimbrai, but it is also tentatively placed in synonymy because of the inadequate illustrations of those workers. Occasionally, specimens with a punctate and smooth external surface are found within a single sample. This is interpreted as being related to the degree of erosion caused by natural post mortem transport of these specimens. Of the illustrated males (Plate 1, figs 5-6), the specimen, which is not eroded (fig. 5), is slightly punctate and the other more eroded specimen (fig. 6) is smooth and probably allochthonous.

Occurrence. Recent, southern Brazilian margin, this species is found from shelf areas to the continental rise. Miocene, Pelotas Basin, borehole 1-RSS $-2,31^{\circ} 19^{\prime} 3.6^{\prime \prime} \mathrm{S} / 50^{\circ} 59^{\prime} 1^{\prime \prime} \mathrm{W}, 1641 \mathrm{~m}$ depth. Geographical and stratigraphic distribution. South Atlantic, Lower Miocene strata (dated by nannofossils, Gomide, 1989) to Recent (Carmo \& Sanguinetti, 1995; Whatley et al., 1998). The species is also known from onshore boreholes in the southern coastal plain (Sanguinetti, 1979; Gomide, 1989); Miocene, Brazil.

Krithe gnoma sp. nov.

(Plate 2, figs 7-11; Fig. 2.2)

1995 Krithe sp. 2 Carmo \& Sanguinetti:, 409, fig. 2B.

1998 Krithe sp. 1 Whatley et al.: pl. 2, figs 1-2.

Derivation of name. Latin 'gnomus', which means diminutive fabled being, dwarf.

Holotype MP-O-1506. Carapace, female; right valve, length $0.63 \mathrm{~mm}$, height $0.32 \mathrm{~mm}$; left valve, length $0.64 \mathrm{~mm}$, height $0.34 \mathrm{~mm}$.

Type locality. Southern Brazilian continental shelf, sample RL3/ $3122,31^{\circ} 02^{\prime} \mathrm{S} / 49^{\circ} 43^{\prime} \mathrm{W}, 131 \mathrm{~m}$ depth, mud with biodetrital sediments.

Horizon. Recent.

Paratype-MP-0-1507. Male, right valve, length $0.57 \mathrm{~mm}$, height $0.27 \mathrm{~mm}$, sample RL3/3228, $25^{\circ} 3^{\prime} \mathrm{S} / 46^{\circ} 39^{\prime} \mathrm{W}, 51 \mathrm{~m}$ depth. Material. Abundant. Carapaces and disarticulated valves. Females, males and young instars well preserved.
Diagnosis. A small species of Krithe, subrectangular in lateral view, greatest height in postero-median area and two frontal muscle scars.

Description. Subrectangular in lateral view, greatest high in postero-median area. Dorsal margin almost straight, ventral margin slightly concave in the antero-median area. Asymmetrical valves, left valve larger than right, overlap in dorsal area. Smooth external surface, hyaline, perforated by normal pore canals type ' $\mathbf{C}$ '. Rounded anterior and truncated at posterior area. Internally, four central muscle scars are disposed in a vertical row, the upper one is reniform and the others regularly elongate. Two frontal scars, the upper one in an ' $\mathbf{L}$ ' shape and the other elongate. Three dorsal muscle scars. Mandibular scar mid-ventral. Narrow marginal zone with a constriction midanterior ventrally. Anterior and posterior vestibula are present, mushroom-shaped and tube-shaped, respectively; the anterior one has a wide neck. Ten marginal pore canals extend from the distal area of the anterior vestibulum. Within the anterior marginal zone, four false marginal pore canals are also present, two in the antero-ventral area and the other two in the anterodorsal area (Fig. 2.2). Strong sexual dimorphism; females swollen in the posterior area and greatest height in the postero-median area. Males greatest high in antero-median area. Dorsal and ventral margins almost straight and parallel.

Remarks. Krithe gnoma has some similarity to $K$. producta Brady, 1880 (in Kaesler \& Lohmann, 1976, figs A, B) but it is easily distinguished by its greatest high in the postero-median area, two frontal scars and a mushroom-shaped anterior vestibulum. On the other hand the species identified as Krithe producta by Kaesler \& Lohmann (1976) has its greatest high in the median area, a trefoil frontal scar and a pocket-shaped anterior vestibulum.

Occurrence. Recent, southern Brazilian margin, this species is found from shelf to continental rise. ?Upper Eocene/Miocene, Pelotas basin within cuttings samples from the borehole 1-RSS-2 $\left(31^{\circ} 19^{\prime} 3.6^{\prime \prime} \mathrm{S} / 50^{\circ} 59^{\prime} 1^{\prime \prime} \mathrm{W}\right)$ at depths of $1971 \mathrm{~m}, 1881 \mathrm{~m}, 1641 \mathrm{~m}$ and $1221 \mathrm{~m}$ and borehole $1-\mathrm{SCS}-3 \mathrm{~B}\left(28^{\circ} 29^{\prime} 30^{\prime \prime} \mathrm{S} / 47^{\circ} 29^{\prime} 6^{\prime \prime} \mathrm{W}\right)$ at $570-585 \mathrm{~m}$ depth.

Geographical and stratigraphic distribution. South Atlantic, ?Upper Eocene/Miocene (Pelotas Basin) dated by correlation with nannofossil biozones (Gomide, 1989) to Recent (Carmo \& Sanguinetti, 1995; Whatley et al., 1998).

Krithe sp. 1

(Plate 1, figs 7-8)

\section{Krithe sp. 6 Carmo \& Sanguinetti: 409, fig. 2F.}

Figured specimen. Right valve, length $0.76 \mathrm{~mm}$, height $0.40 \mathrm{~mm}$. Locality. Southern Brazilian continental slope, sample GVI/358, $31^{\circ} 34^{\prime} \mathrm{S} / 48^{\circ} 52^{\prime} \mathrm{W}, 2500 \mathrm{~m}$. depth, hemipelagic sediments.

Horizon. Recent.

Material. Rare. One damaged right valve.

Remarks. Specific identification is difficult because its occurrence is restricted to one single valve.

Occurrence. Recent, southern Brazilian continental slope.

Geographical and stratigraphic distribution. South Atlantic, Holocene. 


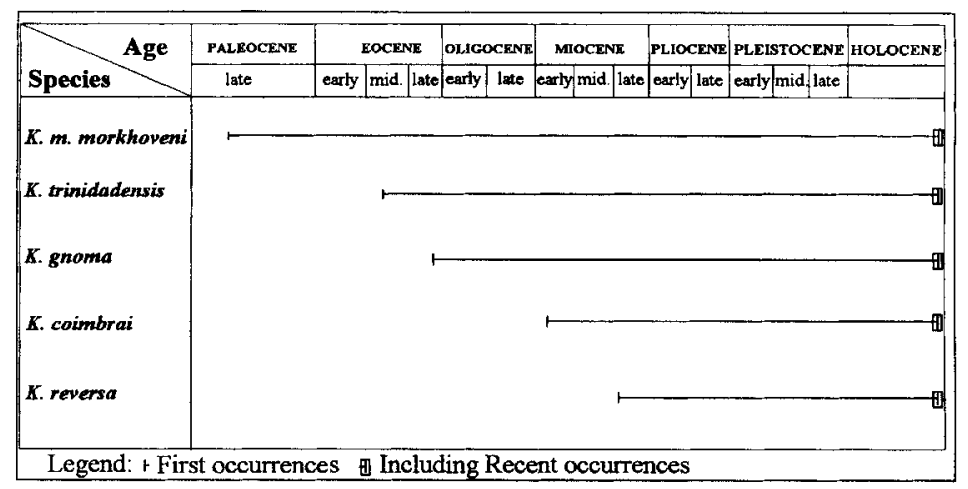

Fig. 3. Stratigraphic distribution of the Krithe species studied.

Krithe sp. 2

(Plate 1, fig. 4)

1995 Krithe sp. 7 Carmo \& Sanguinetti: 409, fig. 2G.

Figured specimens-MP-O-1511. Young instar, left valve, length $0.59 \mathrm{~mm}$, height $0.32 \mathrm{~mm}$.

Locality. Southern Brazilian continental slope, sample GVI/371, $30^{\circ} 45^{\prime} \mathrm{S} / 48^{\circ} 45^{\prime} \mathrm{W}, 800 \mathrm{~m}$ depth, hemipelagic sediments.

Horizon. Recent.

Material. Rare. Disarticulated valves of young instars only.

Remarks. Krithe sp. 2 is left in open nomenclature because its occurrence is restricted to young instars.

Occurrence. Recent, southern Brazilian continental slope.

Geographical and stratigraphic distribution. South Atlantic, Recent.

Krithe sp. 3

(Plate 1, figs 5-6)

1995 Krithe sp. 8 Carmo \& Sanguinetti: 409, fig. 2H

Figured specimens-MP-O-1512. Left valve, length $0.73 \mathrm{~mm}$, height $0.34 \mathrm{~mm}$.

Locality. Southern Brazilian continental slope, sample GII/116$141,3^{\circ} 31^{\prime} \mathrm{N} / 48^{\circ} 19^{\prime} \mathrm{W}$, around $1000 \mathrm{~m}$ depth, sandy mud.

Horizon. Recent.

Material. Rare. One adult left valve.

Remarks. The occurrence of only one valve makes an identification at specific level difficult.

Occurrence. Recent, northern Brazilian continental slope.

Geographical and stratigraphic distribution. North Atlantic, Recent.

Krithe sp. 4

(Plate 1, fig. 9)

Figured specimen-MP-O- 1513. Female, left valve, length $0.85 \mathrm{~mm}$, height $0.51 \mathrm{~mm}$.

Locality. Northern Brazilian continental slope, sample GII/117$143,3^{\circ} 21^{\prime} \mathrm{N} / 48^{\circ} 08^{\prime} \mathrm{W}, 600-560 \mathrm{~m}$ depth, mud.

Horizon. Recent.
Material. Frequent. Two adult valves, male and female, several young instars, well preserved.

Remarks. Despite excellent preservation, it was not possible to identify specifically due to the scarcity of adults.

Occurrence. Recent, northern Brazilian continental slope.

Geographical and stratigraphic distribution. North Atlantic, Recent.

\section{BIOSTRATIGRAPHY}

Four of the nine identified species are left in open nomenclature and have a stratigraphic distribution restricted to the Recent. $K$. reversa Bold, 1958, K. trinidadensis Bold, 1958 and $K . \mathrm{m}$. morkhoveni Bold, 1960 have their first occurrences in the North Atlantic, Upper Paleocene, Middle Eocene and Middle Miocene, respectively (Coles et al., 1994). In the South Atlantic, $K$. trinidadensis and $K . m$. morkhoveni have their oldest occurrences in the Oligocene, with $K$. reversa appearing in the Upper Miocene (Benson \& Peypouquet, 1983). K. coimbrai sp. nov. and $K$. gnoma sp. nov, have their oldest occurrences in the South Atlantic within boreholes in the Pelotas Basin (Fig. 3). $K$. coimbrai first occurrs in the Miocene, borehole 1-RSS-2, and $K$. gnoma in the ?Upper Eocene/Miocene, borehole 1-RRS-2, and in the Miocene, borehole 1-SSC-3B.

The occurrence of $K$. gnoma within cuttings samples at 1971 and $1881 \mathrm{~m}$ in the borehole 1-RSS-2 is dated as ?Upper Eocene by correlation with nannofossil biozones (Gomide, 1989). This interval is suggested as being deposited in an upper bathyal palaeoenvironment (Koutsoukos, 1982). An Eocene age for $K$. gnoma is questionable because it comes from cuttings samples and the rare specimens are worn and broken, possibly suggesting that they were caved from higher levels. This hypothesis of downhole contamination is also supported by the absence of this species in the Oligocene levels of the borehole 1-RSS-2.

Also within the borehole 1-RSS-2, K. gnoma and $K$. coimbrai occur at $1641 \mathrm{~m}$ depth, at an interval dated as Early Miocene (Gomide, 1989). K. gnoma also occurs at $1221 \mathrm{~m}$ depth in a interval dated as Middle Miocene (Gomide, 1989). These two horizons are considered to have been deposited in the upper/ middle bathyal zone. The occurrence of $K$. gnoma in the borehole 1-SSC-3B is at a depth of $585-570 \mathrm{~m}$. This interval is suggested as a shelf palaeoenvironment and dated as Late 
Miocene (Koutsoukos, 1982; Gomide, 1989).

K. coimbrai, in onshore boreholes of the Pelotas Basin, occurs in intervals dated as Early and Late Miocene (Sanguinetti, 1979; Gomide, 1989). These occurrences of $K$. coimbrai are herein interpreted as middle to outer shelf palaeoenvironments based on the Recent shelf occurrence of this species.

This palaeoenvironmental analysis does not indicate that the distribution is the result of upwelling. By analysing the pattern of the faunal succession in these boreholes, two different associations are recognized: (1) Inner shelf warm water; and (2) middle to outer shelf cold water. The inner shelf association is indicated by the presence of the foraminifera Marginopora vertebralis, Amphistegina lessonii and the ostracod Orionina vaughani. The other association, represented by $K$. coimbrai, $K$. gnoma, Callistocythere litoralensis, Cytheretta punctata and Henryhowella indicates relatively colder water and a palaeobathymetry of middle and outer shelf. It would be expected that these two distinct associations would be mixed if aupwelling was the controlling influence.

\section{PALAEOECOLOGY}

The occurrences of $K$. reversa Bold, 1958 and $K$. trinidadensis Bold, 1958 are restricted to the bathyal zone of the northern and southern Brazilian margin, while Krithe sp. 3 and $K$. sp. 4 also occur in the bathyal zone, but restricted to the northern Brazilian margin. $K$. coimbrai sp. nov., $K$. gnoma sp. nov., $K$. $m$. morkhoveni Bold, $1960, K$. sp. 1 and $K$. sp. 2 are restricted to the southern Brazilian margin. $K$. coimbrai and $K$. gnoma are eurybathic species; the others species show a preference for deepwater conditions.

Krithe reversa, $K$. trinidadensis and $K . m$. morkhoveni all have a wide geographical distribution. $K$. reversa and $K . m$. morkhoveni occur in the Atlantic and Pacific oceans (Coles et al., 1994; Carmo \& Sanguinetti, 1995; Ayress, 1985, in Coles et al., 1994; Swain, 1967, 1971a); and K. trinidadensis is found in the Atlantic, Indian and Pacific oceans (Coles et al., (1994); Carmo \& Sanguinetti, 1995; Swain, 1971a,b). Despite their wide geographical distributions, these species are always restricted to the colder and deeper areas of the oceans.

$K$. coimbrai and $K$. gnoma occur in a bathymetric range from shelf to continental slope in the southern Brazilian margin. Considering the occurrences of $K$. sp. 1 and $K$. sp.2 (in Whatley et al., 1998), synonyms of $K$. coimbrai and $K$. gnoma, respectively, it is possible to extend the occurrences of these species into the Argentinean continental margin and also to confirm their eurybathyal habit. The shelf occurrences of these two species are restricted to the southern Brazilian margin and further south into areas under the influence of the Falkland Current (Carmo \& Sanguinetti, 1995; Whatley et al., 1998).

The close ecological relationship between the Recent shelf distribution of $K$. coimbrai and $K$. gnoma in areas under the influence of the Falkland Current in the Brazilian continental margin, make them excellent palaeoceanographical indicators. It is possible, therefore, to infer relatively cold palaeoenvironmental conditions for those levels where these two species are found in the Neogene of the Pelotas Basin (Brazil). The occurrence of these species in association with C. litoralensis (Rossi de Garcia, 1966), C. punctata Sanguinetti, 1979 and specimens of Henryhowella with ocular tubercles (Sanguinetti, 1979) support the present hypothesis of a palaeobathymetry from middle to outer shelf under relatively cold water conditions.

Callistocythere litoralensis is a species characteristic of shelf environments, ranging from 19 to $165 \mathrm{~m}$ on the Brazilian continental shelf, but it is more frequently found at depths below $80 \mathrm{~m}$. Considering the shelf distribution of $C$. litoralensis in this area, its shallowest occurrence is registered farther south in Rio Grande do Sul State (Coimbra et al., 1995), where the influence of the Falkland Current is stronger. This same pattern of shelf distribution is assigned to $K$. gnoma and $K$. coimbrai (Carmo \& Sanguinetti, 1995).

Henryhowella is very common in cold shelf environments (Cronin, 1996). This hypothesis is corroborated by Recent occurrences of species of Henryhowella with ocular tubercles restricted to the southern Brazilian continental shelf (personal communication M. I. Ramos, 1996) in areas under the influence of the Falkland Current.

Considering this palaeoecological setting, it is possible to suggest that the Falkland current was already established in the Miocene (Fig. 4). It is possible, therefore, to corroborate the palaeomagnetic data that indicates the opening of the Drake Passage in the Late Oligocene (Barker \& Burrell, 1977; Kennett, 1982). The opening of the Drake Passage is the important tectonic event that allowed the establishment of the Falkland Current and the circumpolar pattern of ocean circulation (Boltovskoy, 1979, 1980).

\section{DISCUSSION}

The dating of the establishment of the Falkland Current, as well as inferences about the palaeoecology of the Neogene strata within the Pelotas Basin, are polemic subjects. The Falkland Current penetrates into the Brazilian continental margin through the complex Subtropical/Sub-Antarctic Convergence (Boltovskoy, 1979). Within the Subtropical/Sub-Antarctic Convergence, the warm waters of the Brazil Current, which flows from the north, interact with cold waters flowing from the southwest (Falkland Current) (Boltovskoy, 1979; Robinson \& Guymer, 1996). In this convergence, the greater part of the waters from the Falkland Current (higher density) sinks beneath waters from the Brazil Current and reaches north to latitudes around $22^{\circ} \mathrm{S}$ within the Brazilian continental shelf. For oceanographic details of the interaction between the Falkland and the Brazil Currents, see Boltovskoy (1959) and Boltovskoy (1981).

Earlier studies, developed with foraminifera, indicated the establishment of the Falkland Current during the post-Miocene (Boltovskoy, 1979; Boltovskoy, 1980). Benthonic foraminifera, such as $A$. lessonii and $M$. vertebralis in Miocene strata, were used to infer a warm water palaeoenvironment in southern South America (Closs, 1970; Boltovskoy, 1979).

The Recent distribution of $A$. lessonii comprises occurrences within the northern, eastern and southern Brazilian continental margins (Madeira-Falcetta, 1977), where it is confined to the inner shelf (Sprechmann, 1978). In spite of its thermophylic habit (Boltovskoy \& Wright, 1976), this species may reach farther south than $22^{\circ} \mathrm{S}$, the northermost latitude at which the 
Falkland Current influences the shelf areas (Boltovskoy, 1959; Madeira-Falcetta, 1977; Boltovskoy, 1981; Forti-Esteves, 1984; Carmo \& Sanguinetti, 1995), but being restricted to the inner shelf. $M$. vertebralis is also a thermophylic species characteristic of the inner shelf (Boltovskoy \& Wright, 1976).

These foraminifera are found with Orionina, an ostracod genus which is also characteristic of inner shelf areas (Sanguinetti, 1979; Coimbra \& Ornellas, 1989). It is therefore possible to extrapolate the Recent ecological setting of A. lessonii, $M$. vertebralis and Orionina to their Miocene occurrences in the Pelotas Basin. It is here suggested that the warm water conditions of an inner shelf palaeoenvironment be applied to those strata where this association is found.

The establishment of the post-Miocene Falkland Current was based on the thermophylic species described here, in addition to the distribution of foraminifera characteristic of Argentinean and Brazilian subprovinces (Boltovskoy, 1979, 1980). However considering the restriction of the benthonic thermophylic taxa to the inner shelf, it is suggested that this was a result of the stronger influence of the Brazil Current in the southern areas of the South America during the Miocene rather than due to the absence of the Falkland Current during this time.

On the other hand, considering the occurrences of $K$. coimbrai and $K$. gnoma with the ostracods C. litoralensis, C. punctata and Henryhowella in the Miocene of the Pelotas Basin, it is possible to suggest a palaeoenvironment of relatively cold waters in the middle and outer shelves under the influence of the Falkland Current. This corroborates the hypothesis proposed here that the Falkland Current was already established in the Early Miocene.

In the Miocene strata of the Pelotas Basin C. crassa, a benthonic foraminiferid characteristic of the Falkland Current (Madeira-Falcetta, 1977), is also recorded. Other common Recent foraminiferid species of the southern Brazilian Province with occurrences in the Miocene of the Pelotas Basin are Textularia calva (Closs, 1970; Madeira-Falcetta, 1977), Cassidulina curvata, Cibicides bertheloti, Massilina secans, Nonionella atlantica, Planulina faveolata, Quinqueloculina lamarckiana, Textularia candeiana and, a common species in the Argentinean Province, Quinqueloculina seminulum. Other taxa are also recorded in the Miocene of the Pelotas Basin (Closs, 1970; Boltovskoy, 1979).

The suggestion that the middle and outer shelves were under the influence of the Falkland Current on the southern Brazilian margin during the Early Miocene does not disagree completely with palaeoecological inferences based on thermophylic species, but it does limit the warm water conditions to the inner shelf areas. Boltovskoy (1979) and Hoddel \& Kennett (1985) have suggested that the Miocene occurrences of warm water faunas in southern South America are probably the result of a stronger influence by the Brazil Current during this time. This stronger influence is supposed to be related to the relatively warmer climate during the Miocene, as indicated by foraminifera (Bertels, 1975) and by nannofossils (Haq, 1980). This climatic setting may be used to explain the extension of thermophylic faunas southwards during the Miocene rather than removing the influence of the Falkland Current.

Another approach, using the geographical and stratigraphic distribution of Krithe species in the Atlantic, Pacific and Indian oceans, can also be considered. The Recent wide geographical distribution of $K$. reversa, $K$. trinidadensis and $K . m$. morkhoveni in the deep sea may be interpreted as being a consequence of their psychrospheric habit. Thus it would be related to the dynamic connection, at psychrospheric levels, between the Atlantic, Pacific and Indian oceans, maintained by the influence of the NADW and Antaractic Bottom Water.

In the North Atlantic the oldest occurrences of $K . \mathrm{m}$. morkhoveni and $K$. trinidadensis are recorded in Palaeocene and Eocene strata, while, in the South Atlantic, their oldest occurrences are in the Oligocene. These younger appearances in the South Atlantic, compared with the North Atlantic, could be the result of a migration southwards through the NADW mass. This assumption corroborates the hypothesis of the polar or subpolar origin of oceanic deep water in the Oligocene (Hay, 1988), as well as confirming the Oligocene dating of the establishment of the proto-NADW (Benson et al., 1985).

\section{CONCLUSIONS}

Nine species belonging to the genus Krithe have been identified within the Brazilian continental margin: $K$. reversa Bold, 1958 , K. trinidadensis Bold, 1958, K. m. morkhoveni Bold, 1960, K. coimbrai sp. nov. and $K$. gnoma sp. nov., and the four species that have been left in open nomenclature. It is concluded that these species are cryophilic.

Krithe reversa, $K$. trinidadensis and $K . m$. morkhoveni show a preference for psychrospheric conditions and for this reason they have a wide distribution within the largest oceanic basins.

Krithe coimbrai and $K$. gnoma are restricted to the southern Brazilian margin. They are eurybathyal, ranging from the shelf to the continental rise. Their shelf occurrences on the Brazilian continental margin are restricted to zones under the influence of the Falkland Current. This peculiar distribution pattern characterizes them as being oceanographic indicators of the Falkland Current.

Krithe coimbrai and $K$. gnoma can tolerate temperatures up to $15^{\circ} \mathrm{C}$, whereas the other species occur only in colder waters and preferably in deeper zones than those present in shelf areas.

Krithe coimbrai ranges from the Miocene to Recent and $K$. gnoma from ?Upper Eocene/Miocene to Recent. Their occurrences in the Miocene levels of the Pelotas Basin suggest a palaeobathymetry of middle to outer shelf under relatively cold water conditions (below $15^{\circ} \mathrm{C}$ ). This palaeoenvironmental interpretation is supported by the occurrence of foraminiferid species such as $C$. crassa, C. curvata, $T$. calva, C. bertheloti, $M$. secans, $N$. atlantica, P. faveolata, Q. lamarckiana, T. candeiana, $Q$. seminulum, and ostracods such as $C$. litoralensis, C. punctata and Henryhowella, which occurr in the Miocene of the Pelotas Basin.

The Recent shelf occurrences of $K$. coimbrai and $K$. gnoma, allied to the association mentioned above, are used to suggest that the Falkland Current was already established in the Miocene. It is therefore possible to corroborate the hypothesis, based on the palaeomagnetic data, which indicates an opening of the Drake Passage in the Late Oligocene. 


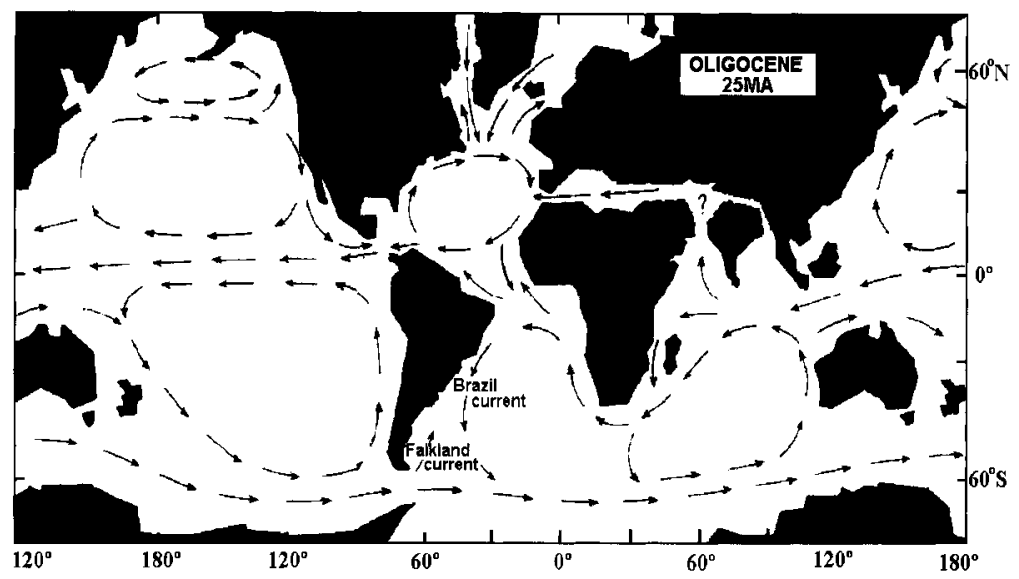

Fig. 4. Surface circulation during the Late Oligocene showing the Falkland and Brazil currents. Adapted from Kennett (1982).

\section{ACKNOWLEDGEMENTS}

This research was funded by the $\mathrm{CNPq}$ (Conselho Nacional de Desenvolvimento Científico e Tecnológico, Brazil). The authors are grateful to CECO (Centro de Estudos Costeiros e Oceanográficos) and PETROBRÁS (Petróleo Brasileiro SA) for the provision of samples from the Brazilian continental margin. For access to their deep-sea Ostracoda collections, the authors are grateful to the staff of the following museums: Micropalaeontology Museum of the University of Wales (Aberystwyth), the Natural History Museum (London) and to the 'Museu de Paleontologia da Universidade Federal do Rio Grande do Sul' (Porto Alegre). The authors thank Drs Roger Kaesler (University of Kansas) and Jaroslav Ríha (Moravian Museum) for the loan of type material; Dr William W. Hay (University of Colorado) for important discussions about the palaeoceanographical evolution of Atlantic ocean; Dr Robin Whatley (University of Wales) for taxonomic and palaeoecological discussions; and Leanne Wilton (University of Wales) and Dr Concepta MacManus Pimentel (Universidade de Brasília) for assistance with the improvement of the English version of the manuscript. The authors are also very grateful to Luiz Flávio Pereira Lopes (Instituto de Geociências-UFRGS) for photographic services.

\section{Manuscript received 2 June 1997 \\ Manuscript accepted 2 August 1999}

\section{REFERENCES}

Barker, P. F. \& Burrell, J, 1977. The opening of Drake Passage. Marine Geology, 25: 15-34.

Bearman, G. 1989. Ocean Circulation. Pergamon Press, London: 238 pp. Benson, R. H. \& Peypouquet, J.-P. 1983. The upper and mid-bathyal Cenozoic faunas of the Rio Grande Rise found on Leg 72. Initial Reports of the Deep-Sea Drilling Project, 72: 805-818.

Benson, R. H., Chapman, R. E. \& Deck, L. T. 1985. Evidence from the Ostracoda major events in the South Atlantic and world-wide over the past 80 million years. In Hsü, K. J. \& Weissert, H. J. (Eds), South
Atlantic Paleoceanography. Cambridge University Press, Cambridge: 325-350.

Bertels, A. 1975. Ostracode ecology during the Upper Cretaceous and Cenozoic in Argentina. Bulletins of American Paleontology, 65: 317351.

Bold, W. A. van den 1958. Ostracoda of the Brasso Formation of Trinidad. Micropaleontology, 4: 391-418.

Bold, W. A. van den 1960. Eocene and Oligocene Ostracoda of Trinidad. Micropaleontology, 6: 145-196.

Bold, W. A. van den 1966. Ostracoda of the Pozon section, Falcon, Venezuela. Journal of Paleontology, 40: 175-185.

Bold, W. A. van den 1968. Ostracoda of the Yague Group (Neogene of the Northern Dominican Republic). Bulletins of American Paleontology, 54: 239-66.

Bold W. A. van den 1981. Distribution of the Ostracoda in the Neogene of Central Haiti. Bulletins of American Paleontology, 79: 7-136.

Boltovskoy, D. 1981. Atlas del Zooplancton del Atlántico Sudoccidental y Métodos de Trabajo con el Zooplancton Marino. UNIDEP (Publicación Especial), Mar del Plata: 936 pp.

Boltovskoy, E. 1959. La Corriente de Malvinas (un estudio en base a la investigación de foraminíferos). Buenos Aires, Ameghiniana, 3-4: 357389.

Boltovskoy, E. 1979. Paleoceanografia del Atlántico Sudoccidental desde el Mioceno, segun estudios foraminiferológicos. Servicio de Hidrografia Naval (Argentina), 1015: 1-96.

Boltovskoy, E. 1980. The age of the Drake passage. Alcheringa, 4: 289297.

Boltovskoy, E. \& Wright, R. 1976. Recent Foraminifera. Junk, The Hague: $515 \mathrm{pp}$.

Brady, G. S. 1880. Report on Ostracoda dredged by H.M.S. Challenger during the years 1873-1876. Zoology, 1: 1-184.

Brady, G. S., Crosskey, H. W. \& Robertson, O. 1874. A Monography of the Post-Tertiary Entomostraca of Scotland (Including England and Ireland). Paleontographical Society: 1-232 pp.

Carmo, D. A. do \& Sanguinetti, Y. T. 1995. Krithe occurrence on the Brazilian continental margin-an ecological approach. In Ríha, J. (Ed.), Ostracoda and Biostratigraphy. Balkema, Rotterdam: 407-412.

Chaves, H. A. F. 1983. Introdução Geral. In Projeto Remac-- Processo e Métodos. Rrelatório final, PETROBRÁS/SINTEC Rio de Janeiro, 132 .

Ciampo, G. 1981. Ostracoda fossili (Oligocene superiore-Serravalliano) del Monte Cammarata (Sicilia Centro-Occidentale) e del Ragusano (Sicilia Sud-Orientale). Bolletino della Società Paleontologica Italiana, 20: $53-72$.

Closs, D. 1970. Estratigrafia da bacia de Pelotas, Rio Grande do Sul. Iheringia, Geologia, 3: 3-76. 
Coimbra, J. C. \& Ornellas, L. P. de 1989. Distribution and ecology of subrecent Orionininae (Ostracoda) in the Brazilian continental shelf. Revista Brasileira de Geociências, 19: 177-186.

Coimbra, J. C., Sanguinetti, Y. T. \& Bittencourt-Calcagno, V. M. 1995. Taxonomy and distribution pattern of Recent species of Callistocythere Ruggieri, 1953 (Ostracoda) from the Brazilian continental shelf. Revista Española de Micropaleontologia, 27: 117-136.

Coles, G. P., Whatley, R. C. \& Moguilevsky, A. 1994. The ostracod genus Krithe from the Tertiary and Quaternary of the North Atlantic. Palaeontology, 37: 71-120.

Cronin, T. M. 1983. Bathyal ostracodes from the Florida-Hatteras slope, the straits of Florida, and Blake Plateau. Marine Micropaleontology, 8: 89-119

Cronin, T.M. 1996. Deep water North Atlantic ostracods and Pliocene palaeoceanography $(3.2-2.8 \mathrm{Ma})$, at DSDP Sites $610 \mathrm{~A}$ and 607 . In Moguilevsky, A. \& Whatley, R. C. (Eds), Microfossils and Oceanic Environments, Proceedings of the $O D P$ and the Marine Biosphere International Conference. Aberystwyth, 1994. University of WalesAberystwyth Press, Aberystwyth: 40-46.

Deltel, M. B. 1964. Noveaux ostracodes de L'Éocène et de l'Oligocène de l'Aquitaine Méridionale. Actes de la Société Linéenne de Bordeaux, 100: $127-221$

Dias, J. L. D., Sad, A. R. E., Fontana, R. L. \& Feijó, F. J. 1994. Bacia de Pelotas. Boletim Geociências da Petrobrás, 8: 235-246.

Dieci, G. \& Russo, A. 1964. Ostracodi Tortoniani dell'Appennino Settentrionale (Tortona, Montegibbio, Castelvetro). Bolletino della Società Paleontologica Italiana, 3: 38-88.

Dingle, R. V., Lord, A. R. \& Boomer, I. D. 1990. Deep-water Quaternary Ostracoda from the continental margin of the SouthWestern Africa. Annals of the South African Museum, 99: 245-366.

Ducasse, O., Guernet, C. \& Tambareau, Y. 1985. Paléogène. In Oertli, H. J. (Ed.), Atlas des Ostracodes de France. Bulletin du Centre de Recherches - Exploration et Production, Elf-Aquitaine, 9: 396.

Forti-Esteves, I. 1984. Recent bivalves (Paleotaxodonta and Pteriomorphia) from the Brazilian continental shelf. Pesquisas, 16: 190-227.

Gomide, J. 1989. Bacia de Pelotas, Biocronoestratigrafia baseada em nanofósseis calcários. In Anais $11^{\circ}$ Congresso Brasileiro de Paleontologia. Curitiba, 1989, Sociedade Brasileira de Paleontologia (SBP), 1: 339-351.

Hanai, T. 1959. Studies on the Ostracoda from Japan IV. Family Cytherideidae Sars, 1925. Journal of the Faculty of Science, 11: 291308

Haq, B. U. 1980. Biogeographic history of Miocene calcareous nannoplankton and paleoceanography of the Atlantic Ocean. Micropaleontology, 26: 414443 .

Hartmann, G. \& Puri, H. S. 1974. Sumary of neontological and paleontological classification of Ostracoda. Mitteilingen Hamburg Zoologischen Museum Institute, 70: 7-73.

Hay, W. W. 1988. Paleoceanography- a review for the GSA Centennial. Bulletin of the Geological Society of America, 100: 1934-1956.

Hodell, D. A. \& Kennett, J. P. 1985. Miocene paleoceanography of the South Atlantic Ocean at 22, 16, and $8 \mathrm{Ma}$. In Kennett, J. P. (Ed.), The Miocene Ocean: Paleoceanography and Biogeography. Geological Society of America, Memoir, 163: 317-337.

Kaesler, R. L. \& Lohmann, K. C. 1976. Phenotypic variations of populations of Krithe producta with environment. Abhandlungen Verhandlung Naturwiss, 18: 279-285.

Kennett, J. P. 1982. Marine Geology. Prentice-Hall, Englewood Cliffs: $813 \mathrm{pp}$.

Koutsoukos, E. 1982. Geohistória e Paleoecologia das bacias marginais de Florianópolis e Santos. In Anais $32^{\circ}$ Congresso Brasileiro de Geologia, Salvador, 1982, Sociedade Brasileira de Geologia (SBG), 5: 2369-2381

Leroy, D. O. \& Levinson, S. A. 1974. Deep-water Pleistocene microfossil assemblage from a well in the northern Gulf of Mexico. Micropaleontology, 20: 1-37.

Madeira-Falcetta, M. 1977. Contribuição ao estudo dos foraminíferos bentônicos da plataforma continental Brasileira (distribuição geográfica e análise batimétrica). Pesquisas, 8: 133-150.

Martins, I. da R. 1984. Aspectos da oceanografia física do Atlântico Sul. Pesquisas, 16: $76-90$.

Moore, R. C. \& Pitrat, C. W. 1961. Treatise on Invertebrate
Paleontology. Part Q. Arthropoda, 3 Crustacea-Ostracoda. Geological Society of America and University of Kansas Press, New York: 442 pp.

Morkhoven, F. P. C. M. van 1962. Post Paleozoic Ostracoda. Their Morphology, Taxonomy and Economic Use. Elsevier, New York: 203 pp.

Oertli, H. J. 1961. Ostracodes du Langhien-Type. Rivista Italiana di Paleontologia, 67: 17-44.

Peypouquet, J.-P. 1977. Les ostracodes et la connaissance des paleomilieux profonds. Applications au Cenozoique de l'Atlantique NordOriental. Université de Bourdeaux 1: 1-433.

Pokorný, V. 1980. The genus Krithe (Ostracoda, Crustacea) in Palaeogene deep-sea deposits in the Zdanice Unit, Moravia, Czecoslovakia. Casopis pro Mineralogii a Geologii, 25: 338-349.

Puri, H. S. \& Dickau, B. E. 1969. Use of the porecanals in Taxonomy of Ostracoda. Transactions of the Gulf Coast Association of Geological Societies, 19: 353-357.

Robinson, I. S. \& Guymer, T. 1996. Observing oceans from space. In Summerhayes, C. P. \& Thorpe, S. A. (Eds), Oceanography - an Illustrated Guide. Manson, London: 69-95.

Rossi de Garcia, E. 1966. Contribucion al conocimento de los ostracodos de la Argentina: 1. Formacion Entre Rios, de Victoria Provincia de Entre Rios. Revista de la Asociación Geológica Argentina, 21: 194-208.

Russo, A. 1968. Ostracodi Tortoniani di Montebaranzone (Appennino Settentrionale Modenese). Bolletino della Società Paleontologica Italiana, 7: 6-56.

Sanguinetti, Y. T. 1979. Miocene ostracodes of the Pelotas Basin, State of Rio Grande do Sul. Pesquisas, 12: 119-187.

Sanguinetti, Y. T., Ornellas, L. P. de, Coimbra, J. C. \& Ramos, M. I. F. 1992. Post-Miocene ostracodes from Pelotas Basin, southern Brasil. Taxonomy-Part II. Pesquisas, 19: 155-156.

Sissingh, W. 1972. Late Cenozoic Ostracoda of the South Aegean Island Arc. Utrecht Micropaleontological Bulletins, 6: 1-187.

Sprechmann, P. 1978. The Paleoecology and Paleogeography of the Uruguayan coastal area during the Neogene and Quaternary. Zitteliana, 4: 3-72.

Steineck, P. L. 1981. Upper Eocene to Midle Miocene ostracode faunas and paleoceanography of the North Coastal Belt, Jamaica, West Indies. Marine Micropaleontology, 6: 339-336.

Steineck, P. L., Breen, M., Nevins, N. \& O'Hara, P. 1984. Middle Eocene and Oligocene deep-sea Ostracoda from the Oceanic Formation, Barbados. Journal of Paleontology, 58: 1463-1496.

Steineck, P. L., Dehler, D., Hoose, E. \& McCalla, D. 1987. Oligocene to Quaternary ostracods of the Central Equatorial Pacific (Leg 85, DSDP-IPOD). In Hanai, T., Ikeya, N. \& Ishizaki, K. (Eds), Evolutionary Biology of Ostracoda. Its Fundamentals and Applications. Proceedings of the $9^{\circ}$ International Symposium on Ostracoda, Kodansha-Elsevier Shizuoka (Japan), 1985: 597-617.

Swain, F. M. 1967. Ostracoda from the Gulf of California. Memoir Series of the Geological Society of America, 101: 1-139.

Swain, G. O. 1971a. Pleistocene Ostracoda from deep-sea sediments in the Southeastern Pacific Ocean. In Funnel, B. M. \& Riedel, W. R. (Eds), The Micropaleontology of Oceans. Cambridge University Press, Cambridge: 487-492.

Swain, G. O. 1971b. Pliocene Ostracoda from deep-sea sediments in the Southwest Pacific and Indian Ocean. In Funnel, B. M. \& Riedel, W. R. (Eds), The Micropaleontology of Oceans. Cambridge University Press, Cambridge: $597-599$.

Vicalvi, M. A. \& Milliman, J. D. 1977. Calcium carbonate sedimentation on continental shelf off southern Brazil, with special reference to benthic foraminifera. In Frost, S. A. et al. (Eds), Reefs and Related Carbonates Ecology and Sedimentology. American Association of Petroleum Geologists, Studies in Geology, 4: 313-328.

Whatley, R. C. \& Quanhong, Z. 1993. The Krithe problem--a case history of the distribution of Krithe and Parakrithe (Crustacea, Ostracoda) in the South China Sea. Palaeogeography, Palaeoclimatology, Palaeoecology, 103: 282-297.

Whatley, R. C., Moguilevsky, A., Chadwick, J., Toy, N. \& Ramos, M. I. F. 1998 Ostracoda from the South West Atlantic. Part III. The Argentinean, Uruguayan and southern Brazilian continental shelf Revista Española de Micropaleontologia, 30(2): 86-116. 
Genus Krithe (Ostracoda) in the Brazilian margin

Yassini, I. 1969. Ecologie des associations d'ostracodes du bassin d'Arcachon et du littoral Atlantique. Application à l'interpretation du quelques populations du Tertiaire Aquitain. Bulletin de l'Institute de Geologie du bassin d'Aquitaine, 7: 1-288.
Zhou, B. \& Ikeya, N. 1992. Three species of Krithe (CrustaceaOstracoda) from Suruga Bay, Central Japan. Transactions and Proceedings of the Paleontological Society of Japan, 166: 1097-1115. 